\title{
Experimental and numerical evaluation of mortar specimens shape and size influence on compression tests
}

\section{Avaliação experimental e numérica da influência da forma e dimensão de corpos de prova de argamassa em ensaios de compressão}
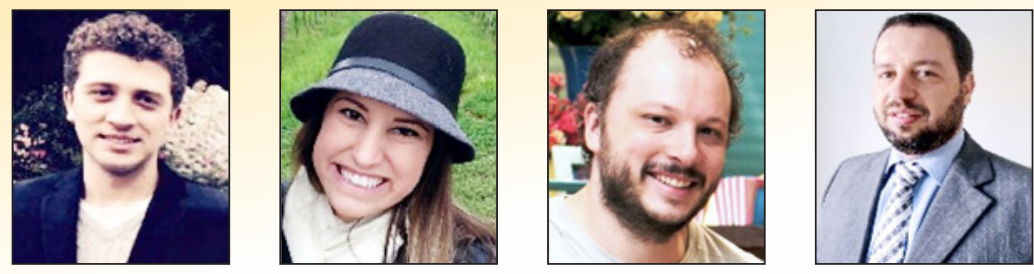

D. F. A. CAPRARO diegocapraro@gmail.com https://orcid.org/0000-0001-5261-5689

A. P. B. CAPRARO anapcapraro@gmail.com https://orcid.org/0000-0001-6270-6568

M. A. ARGENTA a

marco.argenta@ufpr.br https://orcid.org/0000-0003-1183-7896

M. H. F. MEDEIROS a medeiros.ufpr@gmail.com https://orcid.org/0000-0003-3112-9715

\begin{abstract}
The axial compressive strength of cementitious compounds is an important parameter for classification, quality assessment and material design. The values obtained in tests are influenced due intrinsic properties of the compounds and external factors such specimen size and shape. The present work aims to evaluate experimentally and numerically using finite element method, the specimen shape and dimension influence over results of the mortar axial compressive strength test. The specimen geometry aspects are cubic, $(4 \times 4 \times 4) \mathrm{cm}$, column with height/thickness ratio equals two prismatic, $(4 \times 4 \times 8) \mathrm{cm}$, beam with height/thickness ratio equals one prismatic also with dimensions $(4 \times 4 \times 8) \mathrm{cm}$ however tested with horizontal $8 \mathrm{~cm}$ dimension and $5 \mathrm{~cm}$ diameter cylindrical with $5 \mathrm{~cm}$ and $10 \mathrm{~cm}$ of height. Specimen material are strong and weak mortar. We tested five specimen of every mortar strength one for each geometry therefore ten specimen total at 28 days of age. The cylindrical specimen resulted in lower mechanical strength among all geometry. Between cylindrical ones the results exibited equivalent strength however, among prismatic and cubic ones the strength results diverged. Ones with height/thickness ratio equals one, i.e., cubic and beam, resulted in higher strength then one with height/thickness ratio equals two, named column. Numerical simulations verify these results indicating equally height/thickness ratio equals one geometry with higher strength. This could be happening because in height/thickness ratio equals one geometry the maximum principal stress values (tractions) are lower.
\end{abstract}

Keywords: axial compression, strength test, specimen shape, specimen size, numerical analysis.

\section{Resumo}

A resistência à compressão axial de compostos cimentícios é um parâmetro importante para classificação, aferição de qualidade e dimensionamento desses materiais. Os valores obtidos nos ensaios são diretamente influenciados pelas propriedades intrínsecas dos compostos e por fatores externos, como dimensão e forma dos corpos de prova. O presente trabalho tem por objetivo avaliar experimentalmente e numericamente, por meio do método dos elementos finitos, como a forma e a dimensão dos corpos de prova influenciam no resultado do ensaio de resistência à compressão axial de argamassas. Foram ensaiados dois traços de argamassa, um considerado forte e outro fraco, em cinco diferentes configurações, três delas prismáticas, $(4 \times 4 \times 4) \mathrm{cm},(4 \times 4 \times 8) \mathrm{cm}$ (de pé; relação altura/espessura de 2$)$ e $(4 \times 4 \times 8) \mathrm{cm}$ (deitado; relação altura/espessura de 1), e outras duas cilíndricas, com diâmetro de $5 \mathrm{~cm}$ e alturas de $5 \mathrm{~cm}$ e $10 \mathrm{~cm}$. O ensaio foi realizado aos 28 dias de idade e foi notada menor resistência mecânica para os corpos de prova cilíndricos. Quanto às dimensões dos corpos de prova, foi notada resistência equivalente no caso dos cilíndricos para as duas relações altura/diâmetro adotadas $(2,0$ e 1,0). Contudo, o mesmo não ocorreu com os corpos de prova prismáticos, que apresentaram resistências superiores para a relação altura/espessura igual a 1,0. A análise numérica corrobora os resultados obtidos em laboratório, indicando maior resistência dos corpos de prova prismáticos com menor relação altura/espessura, devido aos menores valores de tensões principais de tração.

Palavras-chave: compressão axial, ensaio de resistências, formato do corpo de prova, tamanho do corpo de prova, análise numérica.

Universidade Federal do Paraná, Curitiba, PR, Brasil.

Received: 13 Nov 2017 • Accepted: 27 Jun 2018 • Available Online: 28 Mar 2019

This is an open-access article distributed under the terms of the Creative Commons Attribution License 


\section{Introduction}

The axial compressive strength of cementitious compounds is an important parameter for classification, quality assessment and material design. Its value could be determined by means of uniaxial compression tests of specimens specially molded to this purpose [1].

The specimens may vary in dimension and shape, depending upon the local standards and used materials.

According to Muciaccia, Rosati and Di Luzio [2], despite the size and shape influence of concrete specimens on axial compression test, there are not many studies regarding this effects, when compared to other mechanical tests. For mortar, the available data is smaller because little information is found about.

The aim of this work is study the influence of mortar test specimens shape and dimension variables, when submitted to the axial compression strength test, considering two test specimens dimensions suggested by Brazilian standards, $(4 \times 4 \times 4) \mathrm{cm}$ and $(4 \times 4 \times 8) \mathrm{cm}$, moreover a cylindrical shape of $5 \mathrm{~cm}$ diameter with $5 \mathrm{~cm}$ and $10 \mathrm{~cm}$ heights.

We developed an experimental laboratory program for the study, with two mortar traces for molding the specimens, a rich one (greater amount of binders) and a poor one (smaller amount of binders). In parallel, we also made numerical simulations in a commercial software (SIMULIA ABAQUS R / CAE 6.14), based in finite elements (MEF), for experimental and numerical results comparations.

\section{Literature review}

Brazil specific standards for molding and testing mortar and concrete specimens are NBR 13279 [3] and NBR 5739 [4], respectively. NBR 13279 [3] establishes a method for coating and laying mortars traction (at three point bending) and compressive strength determination at hardened state. About specimens dimensions and shape the standard determines the use of prismatic molds with dimensions equal to $(4 \times 4 \times 16) \mathrm{cm}$. First one must test the specimen, according to
NBR 13279 [3], in traction at three point bending, in which the load is applied at prismatic specimen mid length, breaking it in half, resulting in two parts of approximately $(4 \times 4 \times 8) \mathrm{cm}$. In sequence, the two parts are submitted to axial compression test, with load applied at cross section area $(4 \times 4) \mathrm{cm}$, being ratio height/thickness equal to 1 .

There are, however, another Brazilian standard, NBR 15961-2 [5] aimed to structural masonry that also specifies specimens shape for axial compression strength test. This standard recommend cubic shape, similar to the one specified by American standard ASTM C 109 [6], with different dimensions from the ones presented in NBR 13279 [3] standard $(4 \times 4 \times 4) \mathrm{cm}$. Figure 1 presents the configuration of the test specimens according to Brazilian standards. Depending on the country, different geometric models shapes for concretes compressive strength determination are used. Europe use cubic shape, while Brazil [4], USA [7] and other nations [8] use cylinders. Brazilian standard for concrete compressive strength test, NBR 5739 [4], precognizes the use of cylindrical specimens with the ratio height/diameter $2.02>(\mathrm{h} / \mathrm{d})>1.94$. In cases when the ratio is below 1.94 the standard establishes correction factors ranging from 1 ( $h / d=2.0)$ until $0.87(h / d=1.0)$.

Chin, Mansur and Wee [9] evaluated the influence of the ratio height/ diameter for concrete cylindrical specimens axial compression strength test. According to authors, a ratio $\mathrm{h} / \mathrm{d}$ equal to two is more adequate, because values smaller than 1.5 increases rapidly strength due to bearing plates restriction. For ratios height/diameter ranging from 2.0 to 3.0 the study of Medeiros et al. [10] did not indicate significant differences in concretes of 20 and $30 \mathrm{MPa}$. Literature indicates that, generally, smaller test specimens lead to greater strength, as indicated in studies of $\mathrm{Cu}$ pertino et al. [11] and Kaish et al. [12]. There are studies indicating that stresses and deformations peak decrease when ratio height/thickness is reduced, leading to greater strengths [13].

According to Kaish et al. [12], concrete specimens confinement also leads to greater strength, more accentuated in low ratio height/thickness specimens.

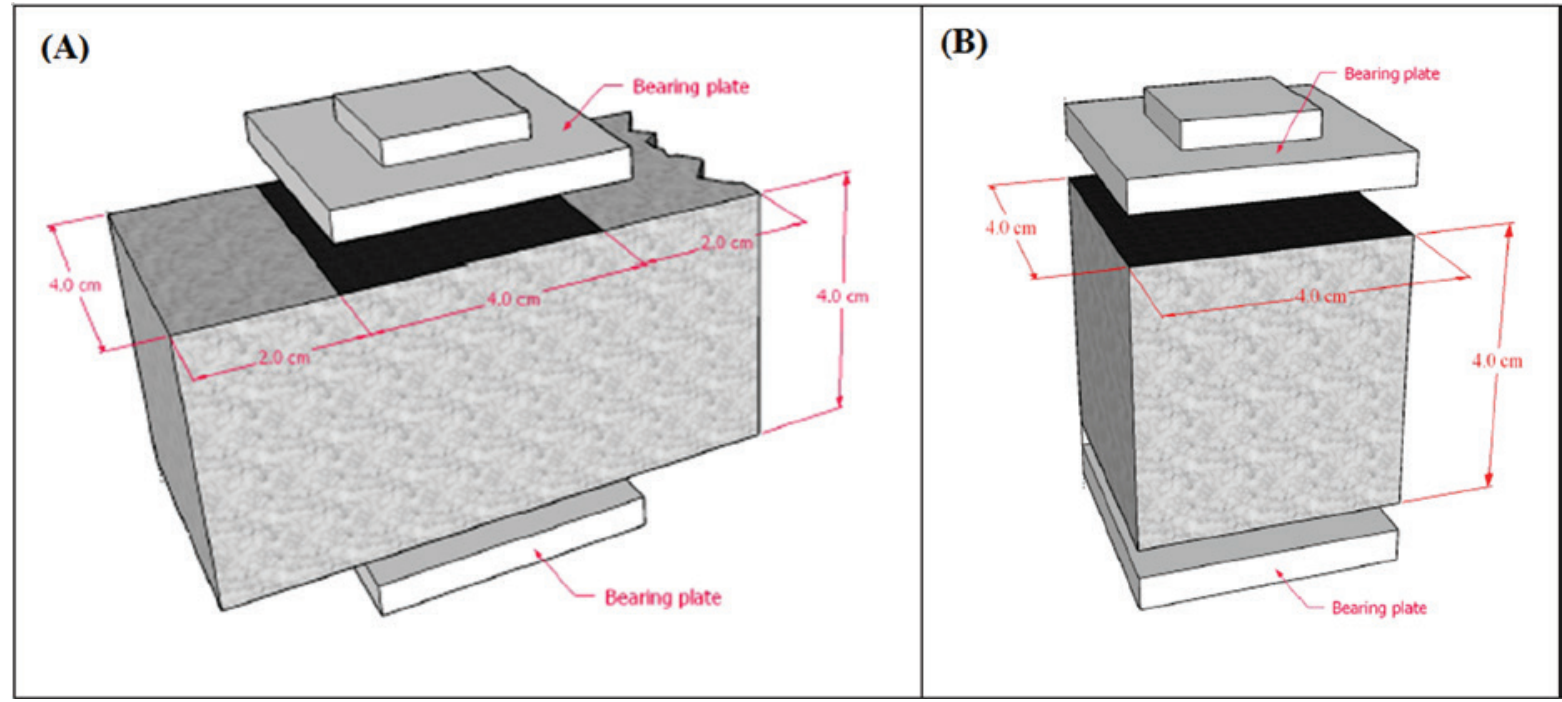

Figure 1

Mortar specimens configurations for the axial compression strength test. (A) Configuration according to NBR 13279 [3]. (B) Configuration according to Annex D of NBR 15961-2 [5] 


\section{Table 1}

Mix proportions used in this work

\begin{tabular}{ccccc}
\hline Mortar type & $\begin{array}{c}\text { Mix proportion } \\
\text { (Cement:Lime:Sand:Water) } \\
\text { by volum }\end{array}$ & $\begin{array}{c}\text { Mix proportion } \\
\text { (Cement:Lime:Sand:Water) } \\
\text { by mass }\end{array}$ & $\begin{array}{c}\text { Ratio } \\
\text { (Water/Binder) }\end{array}$ & $\begin{array}{c}\text { Cement consumption } \\
\left(\mathrm{kg} / \mathrm{m}^{3}\right)\end{array}$ \\
\hline Poor & $1.0: 1.0: 6.0: 4.5$ & $1.0: 0.8: 4.8: 1.5$ & 0.833 & 240 \\
Rich & $1.0: 0.5: 4.5: 3.0$ & $1.0: 0.4: 3.6: 1.0$ & 0.714 & 333 \\
\hline
\end{tabular}

NBR 5738 [14] establishes that specimen diameter should be three times over the coarse aggregate maximum characteristic dimension, in order to simulate properly material conditions of isotropy and homogeneity.

According to BS EN 12504-1 [15] a decrease in concrete specimens diameter also reduces the axial compression strength. This fact was observed in Medeiros at al. [10] work, which same material specimens had greater strengths for $10 \mathrm{~cm}$ diameter when compared with $5 \mathrm{~cm}$ one.

When comparative analysis is made between cylindrical and cubic specimens mechanical strength, authors Hamassaki e Santos [8] affirm that, for the same concrete, the strengths in cubes are greater than the ones obtained in cylinders. Lima e Barbosa [16] have results of correlation between cylindrical test specimens, (15x30) $\mathrm{cm}$ and $(10 \times 20) \mathrm{cm}$, and cubic ones, $(15 \times 15) \mathrm{cm}$ and $(10 \times 10) \mathrm{cm}$. Comparisons made by authors, at the 28 days of concretes age, showed that cylindrical specimens compressive strength was $30 \%$ to $40 \%$ smaller than the cubic ones.

Analyzing the impact of cylindrical and prismatic mortar specimens shape difference, Nalon et al. [17] once again indicates smaller values for cylindrical specimens, especially for weaker traces.

Considering how this specimens fail, Kotsovos [18] said that fissures started to be aligned towards the load in the central zone (Figure 2), at a load level near the maximum load capacity of specimens, and maximum load capacity is reached when the last traction strength of this zone is reached. The researcher also states that the press restriction, due to friction, is fundamental for the specimens rupture mode; however the last load of the test is not altered significantly by this restriction.

Bezerra et al. [19] executed an experimental program whose objective was the analysis of specimens with hourglass shape, corresponding to the central nucleus of cylindrical and prismatic specimen. Results indicate lower influence of press restriction in hourglass shape specimens, when those were compared to cylindrical ones.

\section{Materials and experimental program}

The experimental program consisted in mortar specimens molding aiming to test them for axial compression strength at 28 days of age.
We decided to adopt two traces of mortar, one considered rich (greater amount of binders) and another one poor (smaller amount of binders). Table 1 shows data for this two mortars. Traces were elaborated based on BS EN 998-2 [20] and the amount of water added to the mixture was dosed in order to reach the NBR 13276 [21] requirement, that recommends a consistency index of $260+/$ $5 \mathrm{~mm}$, tested by means of the consistency index table.

The cement used was of type Portland composed, with specific mass equal to $3.00 \mathrm{~g} / \mathrm{cm}^{3}$ and addition to Pozzolana, classified as CP-II-Z 32 according to NBR 5736 [22]. Lime used was of dolomite type, classified as $\mathrm{CH}-\mathrm{III}$ according to NBR 7175 [23] and with specific mass of $2.35 / \mathrm{cm}^{3}$, typically used for masonry laying.

The fine aggregate used was natural sand, from the region of "São Luiz do Purunã". In material characterization tests it had specific mass equal to $2.38 \mathrm{~g} / \mathrm{cm}^{3}$ [24] and content of powdery equal to $10.13 \%$ [25].

The procedure of mortars mixing and axial compression test were done according to Brazilian standards NBR 13276 [21] and NBR 13279 [3], respectively. The mortar had to be previously mixed in slow speed, with the lime, sand and $80 \%$ of kneading water, because it has lime in its composition. After being mixed and weighted it was left in rest during 24 hours in order to avoid late hydration of the lime and possible material fissures. After this interval, it was
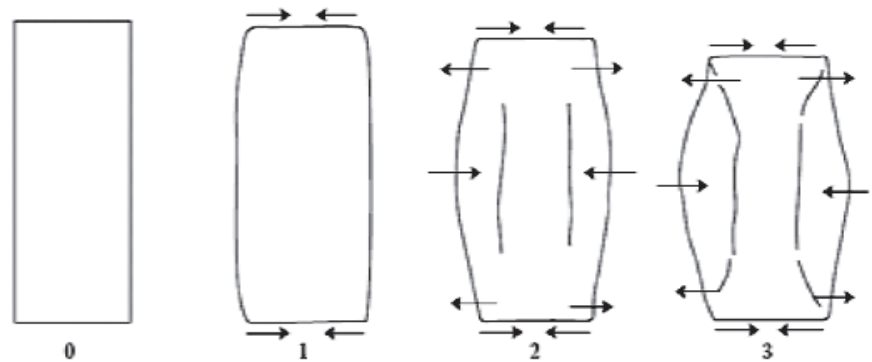

Figure 2

Stages of axial compressive strength test on cylindrical specimens

Source: Kotsovos (2015)

\section{Table 2}

Series studied specimens configuration

\begin{tabular}{cccc}
\hline Name & Shape & Size $(\mathrm{cm})$ & Ratio height/ thickness \\
\hline Pris.8 (Standing) & Prismatic & $(4 \times 4 \times 8)$ & 2 \\
Pris.8 (lying) & Prismatic & $(4 \times 4 \times 8)$ & 1 \\
Pris.4 & Cubic & $(4 \times 4 \times 4)$ & 1 \\
Cil.5 & Cylindrical & $\Phi=5$ and $\mathrm{h}=5$ & 1 \\
Cil.10 & Cylindrical & $\Phi=5$ and $\mathrm{h}=10$ & 2 \\
\hline
\end{tabular}


weighted again and then cement, the remaining of the water and the water lost due to evaporation during the period were added to the mixture.

Five configurations were adopted for the test specimens, three of them prismatic: $(4 \times 4 \times 4) \mathrm{cm},(4 \times 4 \times 8) \mathrm{cm}$ (standing; ratio height/ thickness of 2) and ( $4 \times 4 \times 8) \mathrm{cm}$ (lying; ratio height/thickness of 1 ); and two cylindrical ones, with diameter of $5 \mathrm{~cm}$ and heights of $5 \mathrm{~cm}$ and $10 \mathrm{~cm}$. Table 2 shows the studied series, as well as the nomenclature adopted to each one of them.

Densification was made with vibrating table and, at the end of filling; the upper section of the molds was leveled and protected with plastic film in order to avoid excessive water loss. Unmolding was made 48 hours later and the specimens stored in a dry chamber environment with controlled moisture and temperature (U.R. $<50 \%$ and $20 \pm 2{ }^{\circ} \mathrm{C}$ ), until the age of 28 days for rupture. This type of specimens conditioning was adopted in order to simulate conditions near to what happens with those mortars when applied in works of structural masonry, where no cure is made and the drying of the mortar happens in conditions of work environment.

The specimens rupture was made in a press with maximum capacity of $100 \mathrm{kN}$ of Brand EMIC with load speed of $500 \mathrm{~N} / \mathrm{s}$. In order to ensure the parallelism between the faces of load application were used elastomeric supports, in other words, synthetic rubber reinforced with steel plates, commercially known as neoprene.

For each trace adopted and each configuration of test specimen ten samples were evaluated. Aiming to eliminate spurious values, results differing in $10 \%$ or more of the average were neglected. The averages obtained with the proposed test were statistically evaluated by means of Tukey's test, with $95 \%$ of confidence.

\section{Numerical simulation}

Numerical simulation consisted in modeling axial compression test by means of the finite element method, aiming to verify the influence of shape and ratio height/thickness (h/t) comparing with specimens experimentally tested, using the student software SIMULIAABAQUS R / CAE 6.14.

Tridimensional solid elements (C3D8R) were used in tests, applied to the same specimens geometries tested in experimental pro-

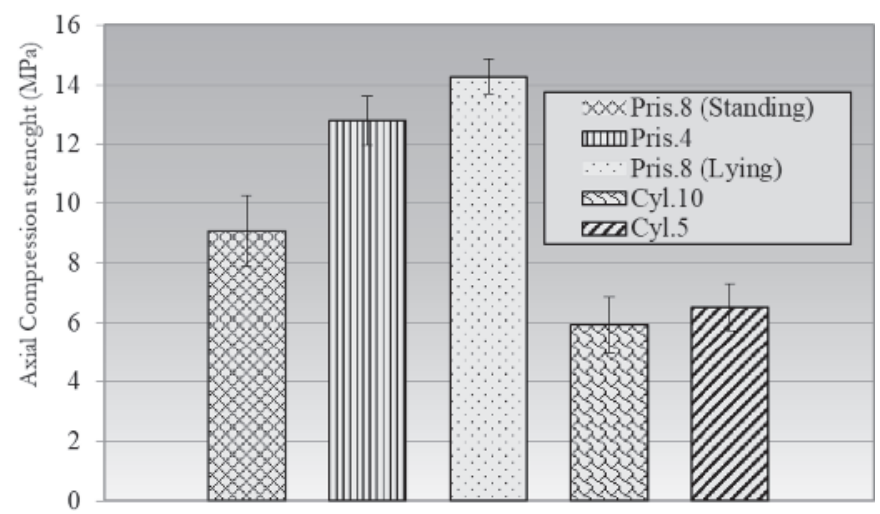

Figure 3

Compression strenght at 28 days in the strong mortar specimens gram. All elements had 8 nodes, 6 degrees of freedom each and second order polynomial interpolation with reduced integration.

The finite element mesh size was considered proper after a mesh convergence test, resulting in elements final size of approximately one twentieth of the thickness of the specimen, in other words, with approximately $5 \mathrm{~mm}$ of edge.

A static load was applied incrementally using load steps in the specimens top representing the test press displacement. Contour conditions restraining vertical displacements at base and horizontal ones at top and bottom faces, representing the friction of the steel of the press and mortar.

Were considered as input data elasticity modulus obtained in the linear portion of compressive strength test curve and constant 0.2 [26] Poisson's coefficient obtained from literature, due to the fact that simulations respect the linear elasticity limit of the material.

\section{Results and discussions}

Results from compressive strength at 28 days allowed the distinction between the two studied mortars, rich and poor, as expected. Figures 2 and 4 show the results obtained for rich and poor trace mortars, respectively. Besides, the mortars standard behavior due to the used specimens influence, was similar for both traces of mortar. Analyzing the results of Figure 3 and 4 and applying Tukey's test, was possible to notice statistical difference for both traces, between prismatic specimens, of ratio height/thickness equal to 1 , being Pris. 8 (lying) more resistant than Pris. 4. The result obtained is coherent, since the condition indicated as more resistant there is a spreading of stresses, generating a greater area of mobilization because, despite the contact area being the same for the configuration of both standards, the area of the transversal section is greater than the one of the lying test specimen (NBR 13279 [3]). This difference between the two series (Pris. 8 lying and Pris. 4) indicates behavioral disagreement, in terms of rupture stress, for configurations proposed by NBR 13279 [3], destined to mortar for lying and coating, and by NBR 15961-2 [5], destined to mortar for structural masonry. This means that there is difference of results between the methods and that the laboratories control cannot generalize those methods of mortar in their internal procedure.

In the comparative analysis of ratio height/thickness of prismatic

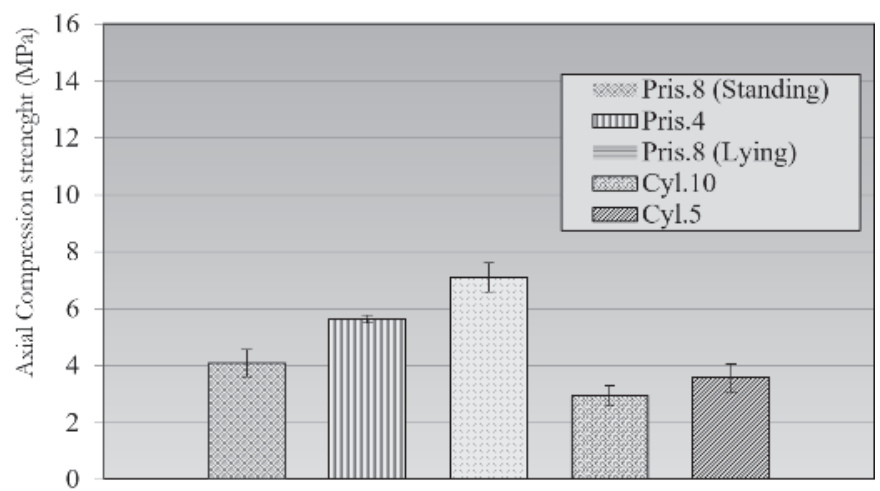

Figure 4

Compression strenght at 28 days in the weak mortar specimens 
specimens it is noted that a ratio equals 1 has greater results when compared with ratio equals 2 . For mortar with rich trace the difference between Pris. 8 lying and Pris. 4 standing, reached $58 \%$, while for poor trace the difference was approximately $73 \%$. The smaller values for ratio height/thickness equal 2 corroborate studies made in concrete specimens, which had greater results for smaller ratios height/thickness, because of bearing plate restriction [12].

Comparatively analyzing the cylindrical specimens, for both traces, it was not possible to state that there was statistic difference between ratios height/thickness studied (1 and 2); in this case the effect of the change of height being less sensible than prismatic configuration one.

Finally, comparatively analyzing the results obtained for prismatic and cylindrical configurations, it was not possible to note that results of cylindrical configurations are smaller when compared to

(A)

\begin{tabular}{|l|}
\hline S, Max. Principal \\
(Avg: 75\%) \\
0.236 \\
0.100 \\
0.000 \\
-0.700 \\
-1.400 \\
-2.091 \\
\hline
\end{tabular}

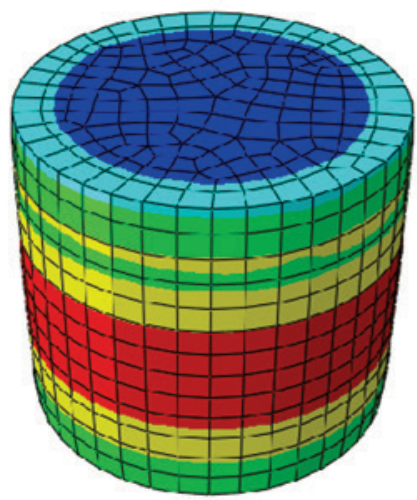

(C)
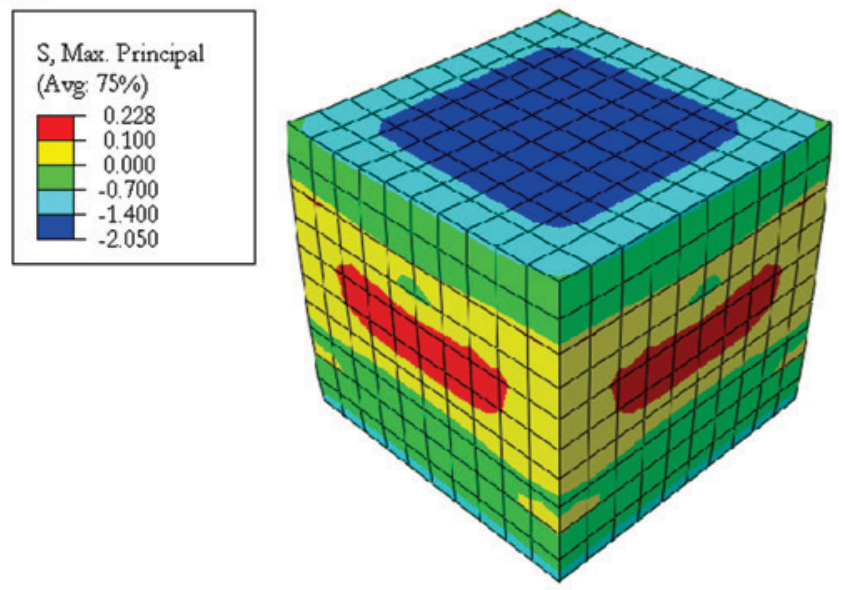

prismatic test specimens, for all cases. This result shows that the behavior of mortars is similar to the concrete one, reported by Lima and Barbosa [16]. For conventional concretes analysis, the mentioned study indicates that the reduction factor from a cubic test specimen to a cylindrical one ranges from $30 \%$ to $40 \%$. Results from this experiment indicate reduction values near $42 \%$, both for rich and poor mortars. However, for the first group this difference was noted between series Pris. 8 (lying) and Cil. 10 and, for the second one, between series Pris 8. (lying) and Cil. 5.

During the numerical analysis were observed greater traction stresses for ratio height/thickness equal 2 for both shapes of test specimens (cylindrical and prismatic), when compared with ratio equals to 1 , according to Figure 5 . In the image it is possible to observe a greater tensioned region in higher test specimens, increasing the probability of fail and causing a smaller rupture strength, as displayed in experimental results.

(B)
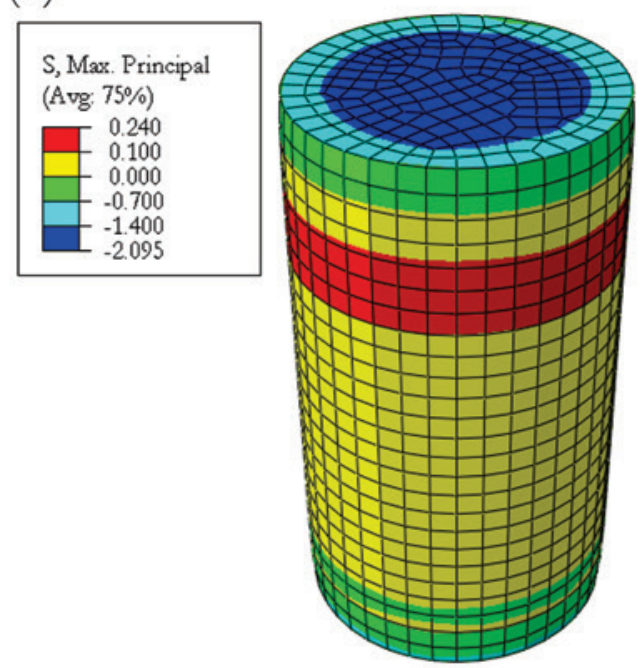

(D)
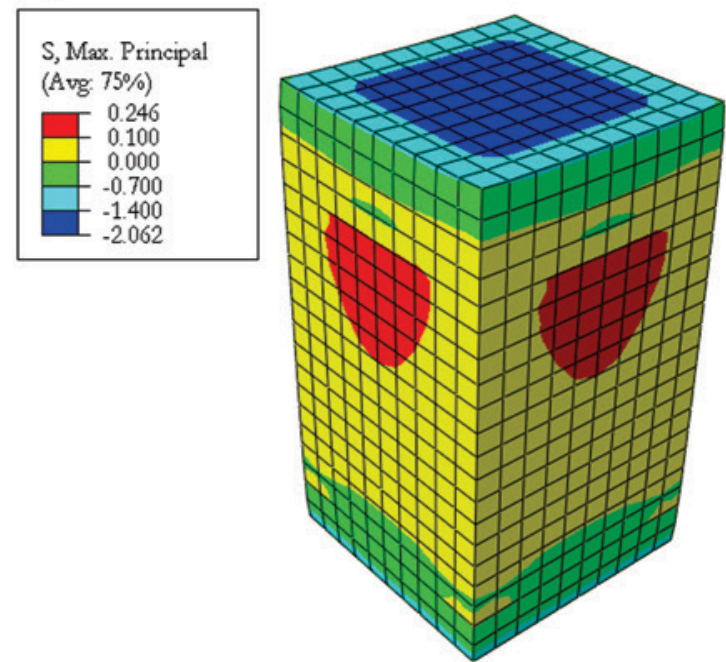

\section{Figure 5}

Numerical results of the maximum main stresses in the specimens: (A) Cyl. 5; (B) Cyl. 10; (C) Pris. 4; (D) Pris. 8 (Up) 
(A)

\begin{tabular}{|l|}
\hline S, Max. Principal (Abs) \\
(Avg: 75\%) \\
\begin{tabular}{|l|}
-8.4 \\
\hline \\
\hline-9.1 \\
-9.8 \\
-10.4 \\
-11.1 \\
-11.8 \\
-12.5 \\
\hline
\end{tabular}
\end{tabular}

\section{Figure 6}

Concentration of stresses in the corners due to the restriction of the press. (A) Numerical simulation; (B) Experimental test

The restriction due to specimen friction face in contact with bearing plate significantly modify stress distribution results. In the model with restricted transverse deformation, formation of stresses is noted at extreme faces of the prismatic test specimen (Pris. 8, standing). Figure 6 illustrate this situation in which transversal stresses
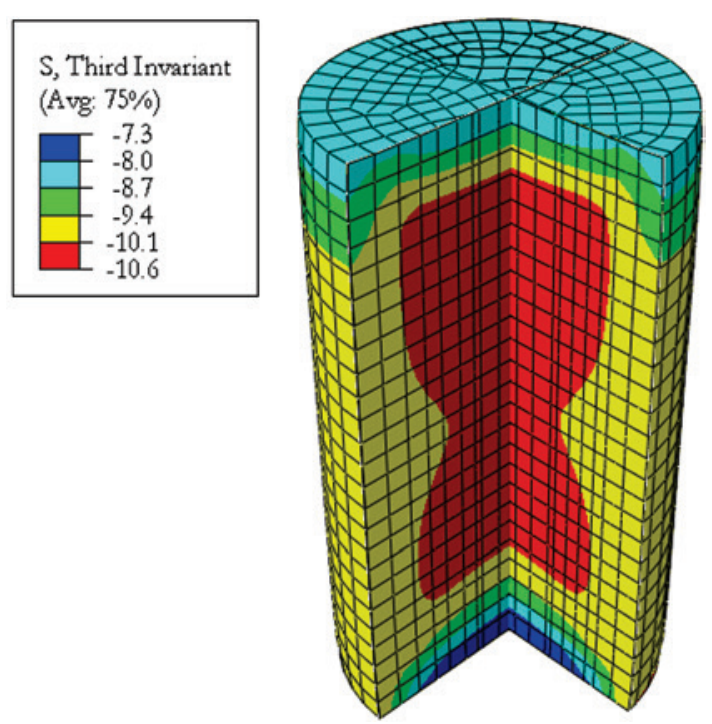

\section{Figure 7}

Distribution of the main stress, core compressed and confined in hourglass format to the cylindrical specimen
(B)

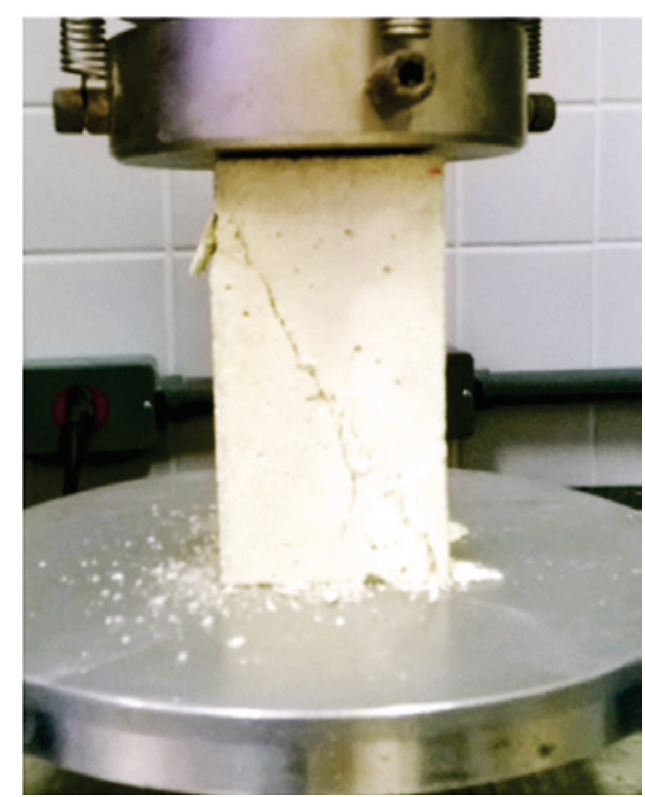

happen near the interface and the corners end up over a state of triaxial compression, due to restriction of the lateral expansion of the test specimen. The experimental tests corroborate this result since the beginning of cracking happens at extremes vertices.

Specimens analysis presented a concentration of vertical stresses in the central part of the test specimen. This generated traction stresses in extremities and created a compressed and confined core in hourglass shape, according to Figure 7. Traction stresses at specimens more external part indicate the propagation of cracks, from outside to inside.

Using the specimen configuration suggested by NBR 13.279 [3], there are lateral areas in balance, forcing rupture dividing specimens in three parts, with central portion in the shape of hourglass. Figure 8 show the distribution of stresses from finite elements simulation and the respective experimental test. The image confirms the distribution of stresses at specimen load application side areas, as previously mentioned.

\section{Conclusions}

Results of this study allowed the understanding of the following aspects:

- Specimens shapes, suggested by the two Brazilian standards, for mortars axial compression strength test (Pris. 4 and Pris. 8 lying), had divergent results, both in experimental as well as in numeric analyzis, thus being possible to point a behavioral difference between formats;

- Test specimen Pris. 8 lying has more resistance than Pris. 4, despite both having the same load application area and the 
(A)

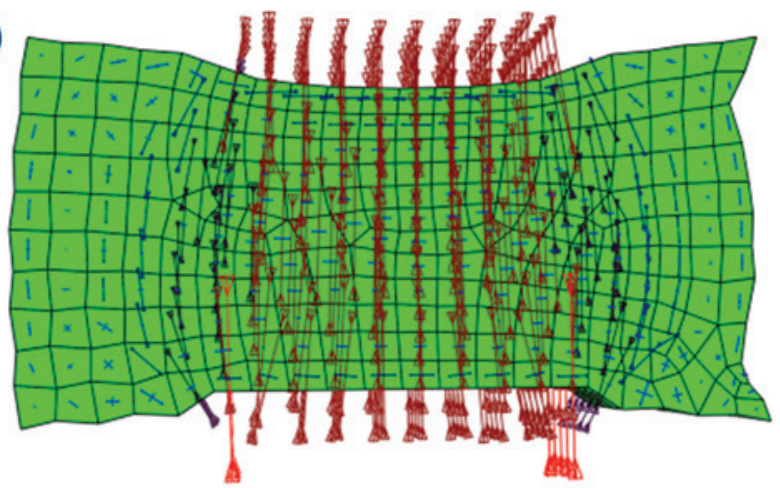

(B)

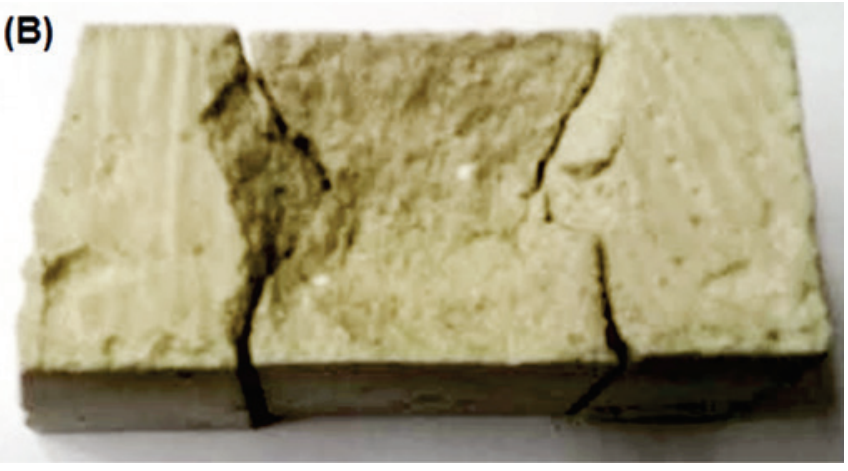

\section{Figure 8}

Failure mode for NBR 13.279 test set configuration [3] (B) Rupture observed in the experimental tests

same height/thickness ratio. This is due to the mobilization of the greater resisting area due to the spreading of stress;

Regarding mortars there is a greater sensibility in the alteration of ratio height/thickness for prismatic test specimens than cylindrical ones;

- There is axial compression strength variation of mortars prismatic specimens when the ratio height/thickness is altered, explained by press plates restriction. Ratio equal to 1 provided greater results than relation equal 2 , with almost $30 \%$ of increase;

- Numerical analysis showed concentration of traction stresses at specimens extremities throughout axial compression test. This result explains the behavior of cracks observed in the experimental tests; this is a cracking from outside to inside.

- Cylindrical specimens (Cil.10 and Cil.5) had smaller results than the prismatic ones (Pris. 8 standing and Pris. 8 lying) and that the cubic one (Pris. 4), in all of the studied cases. The greater percentage of reduction was near $42 \%$, both for the rich and poor trace, comparing series Pris. 8 lying (greater resistance) and the series Cil. 10 (smaller resistance) and comparing Pris. 8 lying (more resistance) with Cil. 5 (the smaller in this case);

- Considering the items listed before it is recommended that the Brazilian standard NBR 13279 [3], in the next revision, adopts test specimen Pris. $4((4 \times 4 \times 4) \mathrm{cm})$, for mortars axial compression test, according to NBR 15961-2 [5], aiming at a greater standardization of results.

\section{Acknowledgements}

The authors thank the infrastructure and the support in human resources and financing to the Coordination of Improvement of Higher Level Personnel (CAPES), to "Fundação Araucária", to CNPq and to "Universidade Federal do Paraná - PPGECC/UFPR".

\section{References}

[1] GRANT, M. R.; SKALNY, J. P. A comparison of vibrated mortar and concrete cube test methods and variability in cube strength development. Cement and Concrete Research. Vol. 16, pp. 561-568. United States, 1986.
[2] MUCIACCIA, G.; ROSATI, G.; DI LUZIO, G. Compressive failure and size effect in plain concrete cylindrical specimens. Construction and Building Materials. Vol. 137, pp. 185-194. 2017.

[3] ASSOCIAÇÃO BRASILEIRA DE NORMAS TÉCNICAS. Argamassa para assentamento e revestimento de paredes e tetos - Determinação da resistência à tração na flexão e à compressão. - NBR 13279, Rio de Janeiro, 2005.

[4] ASSOCIAÇÃO BRASILEIRA DE NORMAS TÉCNICAS. Concreto - Ensaios de compressão de corpos-de-prova cilíndricos. - NBR 5739, Rio de Janeiro, 2007.

[5] ASSOCIAÇÃO BRASILEIRA DE NORMAS TÉCNICAS. Alvenaria estrutural - Blocos de concreto. Parte 2: Execução e controle do obras. - NBR 15961-2, Rio de Janeiro, 2011.

[6] AMERICAN SOCIETY FOR TESTING AND MATERIALS. ASTM C109/C109M-16: Standard Test Method for Compressive Strength of Hydraulic Cement mortars. ASTM International, 2016.

[7] ASTM C192/C192M-02. Standard practice for making and curing concrete test specimens in the laboratory. Annuak book of ASTM standards. Philadelphia, 2002.

[8] HAMASSAKI, L. T.; SANTOS, R. F. C. Corpos de prova Soluções Inovadoras. Revista notícias da construção SINDUSCON. Novembro, 2013.

[9] CHIN, M. S.; MANSUR, M. A.; WEE, T. H. Effects of shape, size and casting direction of specimens on stress-strain curves of high-strength concrete. ACl Materials Journal. V 94, pp. 209-2019. 1997.

[10] MEDEIROS, M. H. F.; CAPRARO, A. P. B.; RÉUS, G. C.; ESCOBEDO, M. L. Resistência a compressão em testemunho de concreto: influência do fator de esbeltez, diâmetro da amostra e método de extração. Revista Eletrônica de Engenharia Civil. Vol. 13, pp. 240-250. 2017.

[11] CUPERTINO, A. L. L.; CASTRO, A.; INÁCIO, J. J.; ANDRADE, M. A. S. Avaliação de fatores de ensaio que interferem nos resultados de módulo de elasticidade do concreto. In: $49^{\circ}$ Congresso Brasileiro do Concreto. Bento Gonçalves, 2007.

[12] KAISH, A. B. M. A.; JAMIL, M.; RAMAN, S. N.; ZAIN, M. F. M. Axial behavior of ferrocement confined cylindrical concrete 
specimens with different sizes. Construction and Building Materials. Vol. 78, pp.50-59. 2015.

[13] SINAIE, S; HEIDARPOUR, A.; ZHAO, X. L.; SANJAYAN, J. G. Effect of size on the response of cylindrical concrete samples under cyclic loading. Construction and Building Materials. Vol. 84, pp.399-408.2015.

[14] ASSOCIAÇÃO BRASILEIRA DE NORMAS TÉCNICAS. Concreto - Procedimento para moldagem e cura de copos de prova. - NBR 5738, Rio de Janeiro, 2015.

[15] BRITISH STANDARDS INSTITUTION DRAFT FOR DEVELOPMENT. BS EN 12504: Testing concrete in structures. London, 2009.

[16] LIMA, F. B.; BARBOSA, A. H. Influência do tamanho e do tipo do corpo de prova na resistência à compressão do concreto. $44^{\circ}$ Congresso Brasileiro do Concreto, IBRACON. Belo Horizonte, 2002.

[17] NALON, G. H.; MARTINS, R. O. G. ; LIMA, G. E. S. ; ALVARENGA, R. C.S. S. Efeito da forma e do tamanho de corpos de prova na determinação da resistência à compressão e deformabilidade de argamassas mistas de cal e cimento. $22^{\circ}$ Congresso Brasileiro de Engenharia e Ciências dos Materiais. Natal, 2016.

[18] KOTSOVOS, M. D. Finite-Element Moldeling of Structural Concrete - Short-Term Static and Dynamic Loading Conditions. CRC Press. London, 2015.

[19] BEZERRA, U. T.; ALVES, S. M. S.; BARBOSA, N. P.; TORRES, S. M. Corpo de prova na forma de ampulheta: resistência à compressão de concretos e argamassas (análises numérica e experimental). Revista IBRACON de estruturas e materiais. Vol. 9 n.4, pp 510-524. IBRACON, 2016.

[20] BRITISH STANDARDS INSTITUTION DRAFT FOR DEVELOPMENT. BS EN 998-2: Specification for mortar for masonry- Part 2: Masonry mortar. London, 2016.

[21] ASSOCIAÇÃO BRASILEIRA DE NORMAS TÉCNICAS. Argamassa para assentamento e revestimento de paredes e tetos - Determinação do índice de consistência. - NBR NM 13276, Rio de Janeiro, 2005.

[22] ASSOCIAÇÃO BRASILEIRA DE NORMAS TÉCNICA. Cimento Portland Pozolânico. - NBR 5736, Rio de Janeiro, 1999.

[23] ASSOCIAÇÃO BRASILEIRA DE NORMAS TÉCNICAS. Cal hidratada para argamassas - Requisitos. - NBR 7175, Rio de Janeiro, 2003.

[24] ASSOCIAÇÃO BRASILEIRA DE NORMAS TÉCNICAS. Agregado miúdo - Determinação da massa específica e massa específica aparente. - NBR NM 52, Rio de Janeiro, 2009.

[25] ASSOCIAÇÃO BRASILEIRA DE NORMAS TÉCNICAS. Agregados - Determinação do material fino que passa através da peneira $75 \mu \mathrm{m}$, por lavagem. - NBR NM 46, Rio de Janeiro, 2003.

[26] NEVILLE, A. M. Propriedades do concreto. $2^{\mathrm{a} e d}$. São Paulo: PINI, 1997. 